\title{
Over-expression of MAGED4B increases cell migration and growth in oral squamous cell carcinoma and is associated with poor disease outcome
}

Type: Journal Article

Abstract:

MAGE proteins have been shown to be good targets for cancer immunotherapy. We demonstrate that MAGED4B is over-expressed in more than $50 \%$ of Oral Squamous Cell Carcinoma (OSCC) tissues and the expression of MAGED4B is associated with lymph node metastasis and poor disease specific survival. OSCC cell lines that overexpress MAGED4B promote migration in vitro, exhibit an increase in cell growth both in vitro and in vivo, and are more resistant to apoptosis compared to control cells. Our data suggest that MAGED4B over-expression is a driver in oral carcinogenesis and argues strongly that this protein may represent a potential therapeutic target in OSCC.

\begin{tabular}{|c|l|}
\hline Author & $\begin{array}{l}\text { Chong, Chan Eng, Lim, Kue PengGan, Chai Phei Marsh, } \\
\text { Christina A. Zain, Rosnah Binti, Abraham, Mannil Thomas, Prime, } \\
\text { Stephen S., Teo, Soo-Hwang, Silvio Gutkind, J., Patel, Vyomesh, } \\
\text { Cheong, Sok Ching }\end{array}$ \\
\hline Source & Cancer Letters \\
\hline ISSN & $0304-3835$ \\
\hline DOI & $10.1016 /$ j.canlet.2012.03.025 \\
\hline Volume (Issue) & Currently Available Online \\
\hline Page & - \\
\hline Year & 2012 \\
\hline
\end{tabular}

Keyword:

MAGED4B, Melanoma antigens, Oral Squamous Cell Carcinoma (OSCC), Migration

Please Cite As:

CHONG, C. E., LIM, K. P., GAN, C. P., MARSH, C. A., ZAIN, R. B., ABRAHAM, M. T., PRIME, S. S., TEO, S.-H., SILVIO GUTKIND, J., PATEL, V. \& CHEONG, S. C. Over-expression of MAGED4B increases cell migration and growth in oral squamous cell carcinoma and is associated with poor disease outcome. Cancer Letters.

URL:

http://www.sciencedirect.com/science/article/pii/S030438351200208X 